\title{
Combined Effect of Vitamin C and E Dose on Type 2 Diabetes Patients
}

\author{
Rajneesh Prajapat ${ }^{1, *}$, Ijen Bhattacharya ${ }^{1}$, Anupam Jakhalia ${ }^{2}$ \\ ${ }^{1}$ Department of Medical Biochemistry, Faculty of Medical Sciences, Rama Medical College and Hospital (NCR), Rama University, India \\ ${ }^{2}$ Department of Medical Biochemistry, Faculty of Medical Sciences, Jawaharlal Nehru Medical College, India
}

Copyright $\bigcirc 2017$ by authors, all rights reserved. Authors agree that this article remains permanently open access under the terms of the Creative Commons Attribution License 4.0 International License

\begin{abstract}
Diabetes is a metabolic disorder that causes vascular complications. As vitamin $\mathrm{C}$ and $\mathrm{E}$ is known for its beneficial effects on blood sugar, serum lipids and glycated haemoglobin $(\mathrm{HbA} 1 \mathrm{c})$. In the present study, we assess the combined effect of vitamin $\mathrm{C}$ and $\mathrm{E}$ on blood sugar (FBS), serum creatinine (SC), total cholesterol (TC), low and high density lipoprotein (LDL, HDL), and glycated haemoglobin (HbAIc) in type 2 diabetes mellitus patients. A total of 50 patients with type 2 diabetes referred to Rama Hospital (NCR), India, were included in the study. They received 500 mg daily twice of both vitamin $\mathrm{C}$ and $\mathrm{E}$ for 4 months. Fasting blood sugar (FBS), serum creatinine (SC), total cholesterol (TC), low and high density lipoprotein (LDL, HDL), and HbAIc were measured before and after vitamin $\mathrm{C}$ and $\mathrm{E}$ consumption and the results were analyzed. A significant decrease in FBS, TC level and non-significant decrease in $\mathrm{SC}$, LDL, and HbAlc level was seen in the patients supplemented with $500 \mathrm{mg}$ of both vitamin $\mathrm{C}$ and $\mathrm{E}$ twice in a day for 4 months. Results indicate that daily consumption of $500 \mathrm{mg}$ of vitamin $\mathrm{C}$ and $\mathrm{E}$ for 4 months may be beneficial for decreasing the FBS, TC, SC, LDL, and HbAlc and slight raise in HDL and calcium level in patients with type II diabetes and thus reducing the risk of complications.
\end{abstract}

Keywords Diabetes Mellitus, Vitamin C and E

\section{Introduction}

Pandit and Pandey [1]; Awasthi et al. [2] proposed that diabetes mellitus is a multi-factorial metabolic disorder and forthcoming epidemic all over the globe that caused due to ineffective secretion of insulin. Prajapat and Bhattacharya [3]; Zhaolan et al. [4] proposed that diabetic patient numbers will possibly rise up to 300 million by 2025 in India. Seyed Hosseini et al. [5] and Rahman Hassan et al. [6] also estimated that 346 million diabetic patients will be increase up to 439 million in 2030 worldwide.
In another study, Khabaz et al. [7] and Manzella et al. [8] explained that, vitamin E supplementation could improve glycemic control. Afkhami-Ardekani et al. [9] and Dakhale et al. [10] proposed that, vitamin $\mathrm{C}$ and glucose show structural similarities, and thus they are effective in prevention of non-enzymatic glycosylation of proteins. Chambial et al. [11] proposed that, vitamin $\mathrm{C}$ is an antioxidant that protects body from damage caused by free radical and also used as therapeutic agent for diseases and disorders. In the study, Simom [11] proposed that, vitamin C acts as regulator of catabolism of cholesterol and Ness et al. [13] proposed beneficial effects on lipids regulation.

In another study, Battisi et al. [14] and Manjunath et al. [15] proposed that, most of patients with diabetes have lipid metabolism disorders; most prevalent forms are decreased high density lipoprotein (HDL) and increased triglyceride. Errikson and Kahvakka [16] proposed that, high doses of ascorbic acid ( $2 \mathrm{gm} /$ day) improved blood glucose regulation and reduce serum cholesterol and triglyceride in type 2 diabetes patients. In another study, Sargeant et al. [17] proposed that, in year 2000 scientist reported an inverse relationship between mean plasma vitamin $\mathrm{C}$ and $\mathrm{HbAlc}$ levels.

We undertook this study to evaluate the effects of vitamin $\mathrm{C}$ and $\mathrm{E}$ supplement on fasting blood sugar (FBS), serum creatinine (SC), total cholesterol (TC), low and high density lipoprotein (LDL, HDL) and HbAIc in patients with type 2 diabetes.

\section{Materials and Methods}

Present study was performed at the Rama Hospital, Rama Medical College (NCR), UP (India), as a randomized controlled trial and with parallel design. According to ADA [18], the whole study size was fifty patients with type 2 diabetic of mean age $52.3 \pm 9.62$ years were selected for the study.

The sex, age, weight, height, duration of diabetes, blood pressure were examined $(\geq 130 / \leq 80 \mathrm{~mm} \mathrm{Hg})$ and recorded. 
Blood samples $(10 \mathrm{ml})$ were drawn from the patients and FBS, serum creatinine (SC), total cholesterol (TC), LDL, HDL, and HbAlc were measured before the initiation of supplementation with vitamin $\mathrm{C}$ and $\mathrm{E}$.

Subjects enrolled in the study received randomly $500 \mathrm{mg}$ of vitamin $\mathrm{C}$ and $500 \mathrm{mg}$ of vitamin $\mathrm{E}$ daily twice for 4 months. The patients were examined and tests were repeated after the duration of 15 days of supplementation with vitamin $\mathrm{C}$ and $\mathrm{E}$.

\subsection{Laboratory Methods}

The blood sugar (FBS), creatinine, total cholesterol, high density lipoprotein (HDL), low density lipoprotein (LDL) and levels of $\mathrm{HbA} 1 \mathrm{c}$ were measured by using Erba kits (Erba Lachema S.R.O., CZ) in the basal state and after the duration of 15 days of treatment. Venous blood $(10 \mathrm{ml})$ was collected from each patient by a certified phlebotomist using standard laboratory methods at each study point. In the study, Powers [19]; Barham and Trinder [20] proposed that, after clotting, blood was centrifuged at $2500 \mathrm{rpm}$ for 30 minutes. The Serum glucose, creatinine (Myers et al. [21]), total cholesterol (Kannel et al. [22]), HDL (Castelli et al. [23]), LDL (Nauck et al. [24]) and HbA1c (Jeppsson et al. [25]) were assayed by colorimetric using Erba Reagent kits with EM 200-Automated Random Access Clinical Chemistry Analyzer [Erba Lachema S.R.O., CZ].

Total cholesterol, triglycerides, LDL, and HDL cholesterol were tested at baseline, subsequently monthly till next 4 months visits. Blood pressure was measured in the baseline and after every 15 days. It was measured in three positions (supine, sitting and upright) in 5 minutes intervals and the mean of them was calculated.

\subsection{Statistical Analysis}

Statistical analysis was performed using Statistical Package for Social Sciences (SPSS 12.0, Chicago IL). Numerical normally distributed data and categorical data were compared using independent t-test. Significance was considered to be $P<0.05$. Results were given with their $95 \%$ CIs. Data were presented as means \pm SD. Numerical normally distributed data and categorical data were compared using independent t-test.

\section{Results and Discussion}

According to Boshtam et al. [26], vitamin E could improve blood sugar in diabetic patients. According to Gazis et al. [27], the alpha tochopherol supplementation [1600 IU] in diabetic patients considerably reduced HbAlc levels. In the study, Paolisso et al. [28] proposed that, the HbA1c levels could be reduced by supplementation of $100 \mathrm{IU}$ vitamin $\mathrm{E}$ in type 1 diabetic patients. Afkhami-Ardekani and Shojaoddiny-Ardekani [29] proposed significant decrease in
FBS, TG, LDL, HbA1c and serum insulin was observed in diabetic patients supplemented with $1000 \mathrm{mg}$ vitamin $\mathrm{C}$. Forghani et al. [30] proposed significant decrease in serum HbA1c and LDL levels observed in diabetic patients supplemented with $1000 \mathrm{mg}$ /day of vitamin C for 6 weeks but according to Bishop et al. [31] supplementation only 500 $\mathrm{mg}$ /day vitamin $\mathrm{C}$ resulted in no significant changes observed in FBS, TC, TG and HbAlc level. Therefore, in present study, the combined doses of vitamin $\mathrm{C}$ and $\mathrm{E}$ [500 $\mathrm{mg} /$ day twice] were supplemented to diabetic patients for 4 months and change in the level of FBS, serum creatinine (SC), total cholesterol (TC), HDL, LDL and levels of HbA1c were measured (Table 1).

A significant decrease for FBS (from $162.78 \pm 4.82$ to $147.09 \pm 7.05, \mathrm{p}=0.00001)$ and total cholesterol (TC) [from $196.11 \pm 9.83$ to $188.75 \pm 2.88, \mathrm{p}=0.00001]$ was observed at 4 months in the $500 \mathrm{mg}$ /day of vitamin $\mathrm{C}$ and $\mathrm{E}$ supplementation. The multiple comparisons analysis showed a borderline, not significant decrease in serum creatinine (SC) for the $500 \mathrm{mg}$ group [vitamin $\mathrm{C}$ and $\mathrm{E}$ ] at 4 months (from $1.32 \pm 0.28$ to $1.19 \pm 0.13 \mathrm{mg} / \mathrm{dl}, \mathrm{P}=0.00183)$, low density lipoprotein (LDL) was (from $128.02 \pm 4.97$ to $123.03 \pm 1.40$, $\mathrm{p}=<0.00001)$ and also in HbA1c level non-significant decline observed at 4 months (from $6.62 \pm 2.404$ to $5.14 \pm$ $1.17, \mathrm{P}=0.00411)$. Non-significant raise observed in high density lipoprotein (HDL) [ from $44.95 \pm 8.13$ to $47.83 \pm 0.74$, $\mathrm{p}=0.00802$ ] and also in calcium level (from $8.91 \pm 0.438$ to $9.35 \pm 0.31, \mathrm{P}=0.00203)$ at 4 months in vitamin $\mathrm{C}$ and $\mathrm{E}$ [500 mg/day twice] supplemented diabetic group (Table 1, Figure 1).

In the study, Afkhami-Ardekani [32] proposed that, the previous clinical trials showed a significant decrease in FBS, LDL and HbA1c levels after usage of $1000 \mathrm{mg}$ of vitamin C or vitamin E separately in type 2 diabetic patients. According to Chen et al. [33] the daily consumption of $800 \mathrm{mg}$ ascorbic acid for 4 weeks by type 2 diabetes patients caused no significant changes in FBS and serum insulin due to use of lower doses. Forghani et al. [34] proposed significant decrease in serum HbA1c and LDL levels observed in patients supplemented with $1000 \mathrm{mg} /$ day of vitamin $\mathrm{C}$ for 6 weeks. Errikson and Kahvakka [35] proposed significant decrease in TC was observed by using 2 gm of vitamin $\mathrm{C}$ for 90 days.

In the study, Mullan [36] proposed that, vitamin $\mathrm{C}$ is required for regeneration of $\alpha$-tocopherol and may thus prevent LDL oxidation in type 2 diabetes patients. Paolisso et al. [37] proposed that, supplementation with $500 \mathrm{mg}$ vitamin $C$ twice daily for 4 months reduced the plasma levels of LDL, TC, TG and insulin significantly. In another study Watts et al. [38] proposed that, administration of $800 \mathrm{IU} /$ day alpha tochopherol for 6 weeks has not beneficial effect on serum glucose and HbA1c in type 2 diabetic women. Cinaz et al. [39] observed that $900 \mathrm{IU} /$ day vitamin E can improve insulin due to oxidative stress reduction. Manzella et al. [40] proposed that, $600 \mathrm{IU} /$ day vitamin $\mathrm{E}$ supplementation reduced $\mathrm{HbA1c}$, plasma insulin and oxidative stress indexes. 
According to Paolisso and Giugliano [41] administration of vitamin $\mathrm{E}$ reduced triglycerides, total cholesterol and LDL. In another study Jain et al. [42] observed that, 100 IU/day vitamin $\mathrm{E}$ in diabetic patients reduced serum triglycerides significantly. Cinaz et al. [43] and Boshtam et al. [44] did not show the effect of vitamin $\mathrm{E}$ on lipids.

According to previous findings, a low dose of single vitamin not causes any significant benefits in diabetes patients. In present study, low combined doses of vitamin $\mathrm{C}$ and vitamin E [500 mg of both] twice daily for 4 months caused significant reduction in FBS, and TC level. There were no significant declines in SC, LDL and HbAlc level after supplementation of vitamin $\mathrm{C}$ and $\mathrm{E}$ [500 $\mathrm{mg}$ of both] twice daily for 4 months. A non-significant raise in HDL and calcium level was observed in patients with type 2 diabetes (Figure 1).

Table 1. The mean values of fasting blood sugar (FBS) serum creatinine (SC), total Cholesterol (TC) high density lipoprotein (HDL), low density lipoprotein (LDL), HbAlc (glycated haemoglobin) before and after supplementation with doses of vitamin C and E [(Data are mean \pm SD)]

\begin{tabular}{|c|c|c|c|c|c|c|}
\hline \multirow{4}{*}{ Variable } & \multirow{4}{*}{$\begin{array}{c}\text { Control } \\
\text { Group Range } \\
(\mathrm{mg} / \mathrm{dl})\end{array}$} & \multicolumn{4}{|c|}{ Diabetic Group } & \multirow{4}{*}{ p value } \\
\hline & & \multirow{3}{*}{$\begin{array}{c}\text { Before Treatment } \\
\mathrm{N}=50 \\
\text { Mean } \pm \mathrm{SD}\end{array}$} & \multicolumn{3}{|c|}{ After Treatment } & \\
\hline & & & \multicolumn{3}{|c|}{$\mathrm{N}=50$} & \\
\hline & & & Mean \pm SD & Variance (SD) & Population SD & \\
\hline FBS (mg/ dl) & $70-110$ & $162.78 \pm 4.82$ & $147.09 \pm 7.05$ & 49.73 & 6.10 & 0.00001 \\
\hline $\mathrm{TC}(\mathrm{mg} / \mathrm{dl})$ & $185-190$ & $196.11 \pm 9.83$ & $188.75 \pm 2.88$ & 8.31 & 2.49 & 0.00001 \\
\hline $\operatorname{HDL}(\mathrm{mg} / \mathrm{dl})$ & $30-65$ & $44.95 \pm 8.13$ & $47.83 \pm 0.74$ & 0.55 & 0.64 & 0.00802 \\
\hline $\mathrm{LDL}(\mathrm{mg} / \mathrm{dl})$ & $80-150$ & $128.02 \pm 4.97$ & $123.03 \pm 1.40$ & 1.96 & 1.21 & $<0.00001$ \\
\hline Calcium (mg/ dl) & $9-11$ & $8.91 \pm 0.438$ & $9.35 \pm 0.31$ & 0.09 & 0.26 & 0.00203 \\
\hline HbA1C (\%) & $4-5.6$ & $6.62 \pm 2.404$ & $5.14 \pm 1.17$ & 1.37 & 1.01 & 0.00411 \\
\hline
\end{tabular}

$\mathrm{P} *<0.05 * *<0.001$ compared to before treatment

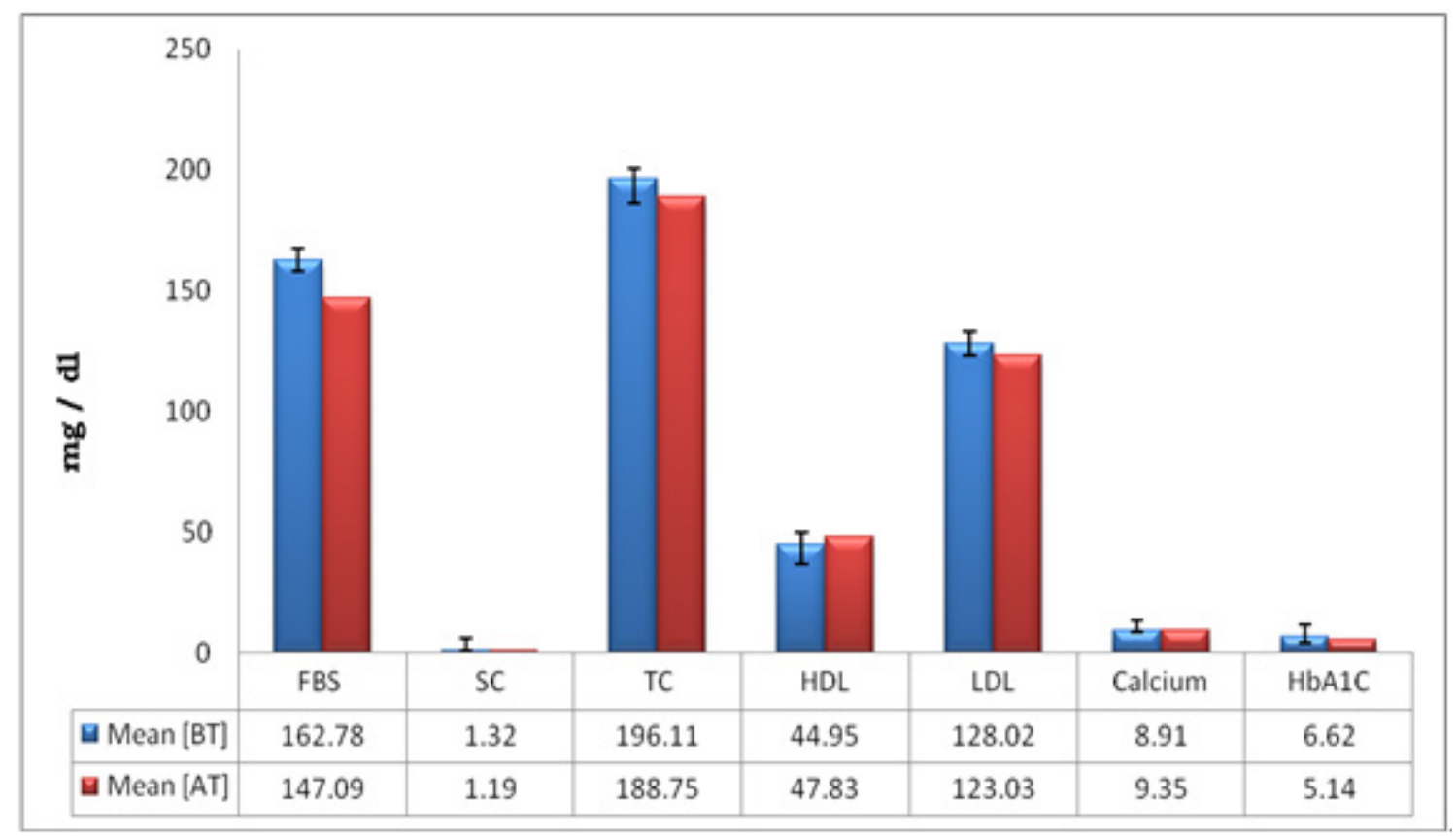

Figure 1. Standard Deviation graph showing mean values and positive, negative error of fasting blood sugar (FBS) serum creatinine (SC), total Cholesterol (TC) high density lipoprotein (HDL), low density lipoprotein (LDL), HbA1c (glycated haemoglobin) before [blue bars] and after [red bars] supplementation / treatment with doses of vitamin $\mathrm{C}$ and $\mathrm{E}[($ Data are mean $\pm \mathrm{SD})]$ 


\section{Conclusions}

In conclusion, supplementation of combined doses [500 $\mathrm{mg}$ /day twice] for 4 months, of vitamin $\mathrm{C}$ and $\mathrm{E}$ in addition to the normal diet may improve plasma glucose (FBS) and lipid profile in patients with type 2 diabetes.

Overall, the significant reduction in FBS, and TC level was seen. There were no significant declines in SC, LDL and HbA1c level. A non-significant raise in HDL and calcium level was observed in patients with type 2 diabetes. Possibly this was due to insufficient samples, dosage or short duration of research. So, further studies with longer duration and higher dosage are suggested. The combined low doses of vitamin $\mathrm{C}$ and $\mathrm{E}$ twice in day may cause similar effect as caused by the higher doses of theses vitamins individually.

\section{Acknowledgements}

The authors are acknowledging to Dr. M. R. Jape (Principal, Rama Medical College, Ghaziabad Utar Pradesh, India) for their precious support and approval of present study project. We are grateful to the Biochemistry laboratory research group for their active co-operation.

\section{REFERENCES}

[1] Pandit A, Pandey AK. Estimated Glomerular Filtration Rate and Associated Clinical and Biochemical Characteristics in Type 2 Diabetes Patients. Adv in Diabetes and Metabol. 2016; 4: 65 - 72. doi: 10.13189/adm.2016.040402.

[2] Awasthi A, Parween N, Singh VK, Anwar A., Prasad B, Kumar J. Diabetes: Symptoms, Cause and Potential Natural Therapeutic Methods. Adv. in Diabetes and Metabolism. 2016; 4, 10-23. doi: 10.13189/adm.2016.040102.

[3] Prajapat R, Bhattacharya I. In-silico Structure Modeling and Docking Studies Using Dipeptidyl Peptidase 4 (DPP4) Inhibitors against Diabetes Type-2. Adv in Diabetes and Metabol. 2016, 4: 73-84. doi: 10.13189/adm.2016.040403.

[4] Zhaolan L, Chaowei F, Weibing W, Biao X. Prevalence of chronic complications of type 2 diabetes mellitus in outpatients-a correstional hospital based survey in urban China. HQLO. 2010; 8: 62-71.

[5] Seyed Hosseini S M, Mardanshahi A, Heidari S S, Sadr-Bafghi S M H, Sadr-Bafghi S A. Depression and Glycemic Control in Type II Diabetic Patients Iranian J of diabetes and obesity. 2015; 7 (3):112-117.

[6] Rahman Hassan SAEL, Rahman Elsheikh WA, Abdel Rahman NI, Nabiela M. ElBagir. Serum Calcium Levels in Correlation with Glycated Hemoglobin in Type 2 Diabetic Sudanese Patients. Adv in Diabetes and Metabolism. 2016, 4: 59 - 64. doi: 10.13189/adm.2016.040401.

[7] Khabaz M, Rashidi M, Kaseb F, Afkhami-Ardekan M. Effect of Vitamin E on Blood Glucose, Lipid Profile and Blood
Pressure in Type 2 Diabetic Patients. Iranian J of diabetes and Obesity. 2009; 1 (1): 10-15.

[8] Manzella D, Barbieri M, Ragno E, Paolisso G. Chronic administration of harmacologic doses of vitamin $\mathrm{E}$ improves the cardiac autonomic nervous system in patients with type 2 diabetes. Am J Clin Nutr. 2001; 73: 1052-1057.

[9] Afkhami-Ardekani M, Vahidi AR, Borjian L, Borjian L. Effect of vitamin $\mathrm{C}$ supplement on glycosylated hemoglobin in patients with type 2 diabetes. J Shah Sad Univ.2003; $10: 15-8$.

[10] Dakhale G N, Chaudhari H V, Shrivastava M. Supplementation of Vitamin C Reduces Blood Glucose and Improves Glycosylated Hemoglobin in Type 2 Diabetes Mellitus: A Randomized, Double-Blind Study. Adv in Pharmacological Sciences, vol. 2011, doi:10.1155/2011/195 271

[11] Chambial S, Dwivedi S, Shukla KK, John PJ, and Sharma P.Vitamin C in Disease Prevention and Cure: An Overview. Indian J Clin Biochem. 2013; 28 (4): 314-328. doi: $10.1007 / \mathrm{s} 12291-013-0375-3$

[12] Simom JA. Vitamin C and cardiovascular disease: a review. JAm Coll Nutr.1992; 11: 107-25.

[13] Ness AR, Khaw KT, Bingham S, Day NE. Vitamin C status and serum lipids. Eur J Clin Nutr1996; 5: 724-9.

[14] Battisi WP, Palmisano J, Keane WE. Dyslipidemia in patients with type 2 diabetes: Relation between lipids, kidney disease and cardiovascular disease. Clin Chem Lab Med.2003; 41: 881-91.

[15] Manjunath CN, Rawal JR, Irani PM, Madhu K. Atherogenic dyslipidemia. Indian J Endocrinol Metab. 2013, 17(6): 969976. doi: $10.4103 / 2230-8210.122600$

[16] Errikson J, Kahvakka A. Magnesium and ascorbic acid supplementation in diabetes mellitus. Ann Nutr Metab. 1995; 39: $217-23$

[17] Sargeant LA, Wareham NJ, Bingham Luben RN, Oakes S, Welch A, et al. Vitamin C and hyperglycemia in the European prospective investigation into cancer- Norfolk (EPIC-Norfolk) study. Diabetes Care.2000; 23: 726-32.

[18] American Diabetes Association. Standards of medical care in diabetes-2006. Diabetes Care. 2006; 29:4-42.

[19] Powers AC.: Diabetes mellitus. Harrison's principles of internal medicine, $15^{\text {th }}$ edition. Edited by Braunwold E, Favci AS, Kasper DL, Hauser SL, Lorgo DL, Jameson JL, editors. New York: McGraw Hill; 2001: 2124-5.

[20] Barham D and Trinder P. An improved color reagent for the determination of blood glukose by the oxidase system. Analyst. 1972, 97: 142 - 5.

[21] Myers GL, Miller WG, Coresh J, Fleming J, Greenberg N, Greene T, Hostetter T, Andrew SL, Panteghini M, Welch M, Eckfeldt JH. Recommendations for Improving Serum Creatinine Measurement: A report from laboratory working group of the National kidney disease education program. Clinical Chemistry. 2006; 52 (1): $5-18$.

[22] Kannel WB, Castelli WP, Gordon T. Cholesterol in the prediction of atherosclerotic disease; new perspectives based on the Framingham study. Ann Intern Med. 1979; 90:85. 
[23] Castelli WP, Doyle JT, Gordon T, Hames CG, Hjortland MC, Hulley SB, Kagan A and Zukel WJ (). HDL cholesterol and other lipids in coronary heart disease. The cooperative lipoprotein phenotyping study. Circulation. 1977; 55: 767-772

[24] Nauck M, Warnick GR, Rifai N. Methods for Measurement of LDL-Cholesterol: A Critical Assessment of Direct Measurement by Homogeneous Assays versus Calculation. Clinical Chemistry, 2002; 48 (2): 236-254.

[25] Jeppsson JO, Kobold U, Barr J, Finke A, Hoelzel W, Hoshino T, Miedema K, Mosca A, Mauri P, Paroni R, Thienpont L, Umemoto M, Weykamp C. Approved IFCC reference method for the measurement of $\mathrm{HbA1c}$ in human blood. Clin Chem Lab Med. 2002; 40(1):78-89.

[26] Boshtam M, Rafiei M, Golshadi ID, Ani M, Shirani Z, Rostamshirazi M. Long term effects of oral vitamin E supplement in type II diabetic patients. Int J Vitam Nutr Res. 2005; 75(5):341-6.

[27] Gazis A, White DJ, Page SR, Cockcroft JR. Effect of oral vitamin $\mathrm{E}$ (alpha-tocopherol) supplementation on vascular endothelial function in Type 2 diabetes mellitus. Diabetic Medicine. 1999; 16(4):304-311.

[28] Paolisso G, D’Amore, Galzerano D, Balbi V, Giugliano D, Varricchio M, D'Onofrio F. Daily vitamin E supplements improve metabolic control but not insulin secretion in elderly type II diabetic patients. Diabetes Care. 1993; 16: 1433-1437.

[29] Afkhami-Ardekani M, Shojaoddiny-Ardekani A. Effect of vitamin $\mathrm{C}$ on blood glucose, serum lipids \& serum insulin in type 2 diabetes patients. Indian J Med Res. 2007; 126 (5):471-4.

[30] Forghani B, Goharian V, Kassayian N, Amini M. The effect of vitamin $\mathrm{C}$ supplements on serum lipoprotein levels in NIDDM patients. J M C Isfahan Univ. 2001; 2: 95-100.

[31] Bishop N, Schorah CJ, Wales JK. The effect of vitamin C supplementation on diabetic hyperlipidaemia: a double blind, crossover study. Diabet Med. 1985; 2: 121-4.

[32] Afkhami-Ardekani M, Mohiti J, Amirchaghmaghi E, Modarresi M. The effect of vitamin C supplementation on insulin level, HbAlc and blood glucose in type 2 diabetic patients. J Beh Kerm Univ Med Sci. 2006; 11: 12-8.

[33] Chen H, Karne RJ, Hall G, Campia U, Panza JA, Cannon RO, et al. High-dose oral vitamin $\mathrm{C}$ partially replenishes vitamin $\mathrm{C}$ levels in patients with type 2 diabetes and low vitamin $\mathrm{C}$ levels but does not improve endothelial dysfunction or insulin resistance. Am J Physiol Heart Circ Physiol.2006; 290: H13745.

[34] Forghani B, Goharian V, Kassayian N, Amini M. The effect of vitamin $\mathrm{C}$ supplements on serum lipoprotein levels in NIDDM patients. J M C Isfahan Univ.2001; 2: 95-100.

[35] Errikson J, Kahvakka A. Magnesium and ascorbic acid supplementation in diabetes mellitus. Ann Nutr Metab.1995; 39: 217-23.

[36] Mullan BA, Young IS, Fee H, McCance DR. Ascorbic acid reduces blood pressure and arterial stiffness in type 2 diabetes. Hypertension. 2002; 40: 804-9.

[37] Paolisso G, Balbi V, Volpe C, Varricchio M, Gambardella A, Saccomanno F, et al. Metabolic benefits deriving from chronic vitamin $\mathrm{C}$ supplementation in aged non-insulin dependent diabetics. J Am Coll Nutr. 1995; 14: 387-92.

[38] Watts GF, Playford DA, Croft KD, Ward NC, Mori TA, Burke V. Coenzyme Q10 improves endothelial dysfunction of the brachial artery in Type II diabetes mellitus. Diabetologia. 2002; 45(3):420-426.

[39] Cinaz P, Hasanoglu A, Bideci A, Bilberoglu G. Plasma and erythrocyte vitamin E levels in children with insulin dependent diabetes mellitus. J Pediatr Endocrinol Metab. 1999; 12:193-196.

[40] Manzella D, Barbieri M, Ragno E, Paolisso G. Chronic administration of harmacologic doses of vitamin $\mathrm{E}$ improves the cardiac autonomic nervous system in patients with type 2 diabetes. Am J Clin Nutr. 2001; 73: 1052-1057.

[41] Paolisso G, Giugliano D. Oxidative stress and insulin action. Is there a relationship. Diabetologia. 1996; 39:357-363.

[42] Jain SK, McVie R, Jaramillo JJ, Palmer M, Smith T. Effect of modest vitamin E supplementation on blood glycated hemoglobin and triglyceride levels and red cell indices in type I diabetic patients. J of the Am College of Nutr. 1996; 15(5):458.

[43] Cinaz P, Hasanoglu A, Bideci A, Bilberoglu G. Plasma and erythrocyte vitamin $\mathrm{E}$ levels in children with insulin dependent diabetes mellitus. J Pediatr Endocrinol Metab. 1999; 12: $193-196$.

[44] Boshtam M, Rafiei M, Sarraf-Zadegan N. Effect of vitamin E supplementation on type II diabetic patients. J of Shaheed Sadoughi Univ of Medi Sci and Health serv. 2003; 10: 32-40. 